Jasna S. Uhlarik

UDK 371.3:811.162.4

Zuzana M. Tirova

Originalan naučni rad

Univerzitet u Novom Sadu

10.19090/mv.2016.7.277-294

Filozofski fakultet, Novi Sad

Odsek za slovakistiku

jasna.uhlarik@gmail.com

zuzana.tyrova@gmail.com

\title{
MORFOLOŠKE, SINTAKSIČKE I LEKSIČKE GREŠKE UČENIKA ČIJI JE MATERNJI JEZIK SRPSKI PRI US- VAJANJU SLOVAČKOG KAO BLISKOG SLOVENSKOG JEZIKA ${ }^{1}$
}

\begin{abstract}
APSTRAKT
Predmet ovog rada su tipične jezičke greške koje se javljaju kod polaznika početnog kursa slovačkog jezika (kao stranog) čiji je maternji jezik srpski. U radu su kroz opis slovačkog jezičkog sistema posmatrane, zabeležene i analizirane tipične morfološke, sintaksičke i leksičke greške polaznika s osvrtom na odsustvo ili razlike u vezi sa funkcionisanjem pojedinih jezičkih pojava: paralele, slaganja i sličnosti nasuprot diferencijama, razlikama i kontrastima u slovačkom i srpskom jeziku. Cilj ovog rada jeste da se rezultati istraživanja primene u nastavi, kao i tokom određivanja adekvatne didaktičke koncepcije i metodičkih postupaka u nastavi.
\end{abstract}

Ključne reči: slovački kao strani jezik, srpski kao maternji jezik, međujezička interferencija, morfologija, sintaksa, leksika, analiza tipičnih grešaka, primena rezultata.

1 Ovaj rad predstavlja fazne rezultate u okviru republičkog projekta Diskursi manjinskih jezika, književnosti i kultura u jugoistočnoj i srednjoj Evropi (broj projekta: 178017, rukovodilac projekta: prof. dr Miroslav Dudok) koji finansira Ministarstvo prosvete, nauke i tehnološkog razvoja Republike Srbije. 


\title{
MORPHOLOGICAL, SYNTACTICAL, AND LEXICAL ERRORS OF STUDENTS WHOSE MOTHER TONGUE IS SERBIAN WHILE LEARNING SLOVAK AS SIMILAR SLOVENIAN LANGUAGE
}

\begin{abstract}
This paper focuses on the typical language errors that occur among students of elementary Slovak language (as foreign language) whose native language is Serbian. The paper presents the description of the Slovak language system through observed, recorded and analyzed typical morphological, syntactic and lexical errors of students with an overview of absence or differences related to the functioning of certain linguistic phenomena: parallels, concurrences and similarities as opposed to differences and contrasts in Slovak and Serbian language. The aim of this study is the possibility of applying the results of this research in teaching, as well as in determining the appropriate didactic concepts and methodological procedures in the classroom.
\end{abstract}

Key words: Slovak as a foreign language, Serbian as a mother tongue, inter-linguistic interference, morphology, syntax, lexicon, analysis of common errors, applying results

\section{UVOD}

Slovački kao strani jezik pripada primenjenoj lingvistici. Pored izučavanja slovačkog kao stranog jezika obuhvata istraživanja savremenog slovačkog jezika u vezi sa interpretiranjem i usvajanjem gramatičkog i leksičkog sistema, kao i usvajanjem pravila praktične komunikacije uzimajući u obzir unutarjezičke i međujezičke odnose. Slovački kao strani jezik se na Filozofskom fakultetu u Novom Sadu izučava od školske 2008/2009. godine. Polaznici ovog kursa su studenti kojima je maternji jezik srpski i koji nemaju nikakvo predznanje iz slovačkog jezika. Uzimajući u obzir karakter kursa i ciljnu grupu, u okviru ovog predmeta se primenjuje prvenstveno komunikativna metoda izučavanja jezika, a umesto starijih klasičnih gramatika koristi se aktuelna i savremena literatura, udžbenici koje izdaje Metodički centar Studia Academica Slovaca. ${ }^{2}$

2 Kamenárová, R., Gabríková, A., Ivoríková, H., Španová, E., Mošatová, M., Balšínková, D., Kleschtová, Z., Tichá, H. (2007). Krížom-krážom. Slovenčina A1. Bratislava: Univerzita Komenského; Kamenárová, R., Gabríková, A., Ivoríková, H., Španová, E., Mošatová, M., Balšínková, D., Kleschtová, Z., Tichá, H. (2009). Krížom-krážom. Slovenčina A2. Bratislava: Univerzita Komen- 
Odsek za slovakistiku Filozofskog fakulteta u Novom Sadu nudi studentima početni kurs, tj. nivoe A1 i A2. Cilj kursa jeste sticanje osnovnih komunikativnih kompetencija na slovačkom jeziku koje podrazumevaju standardno sporazumevanje u svakodnevnim situacijama. Uzimajući u obzir savladan stepen učenja jezika, kod polaznika se razvijaju pojedine komunikativne veštine: od receptivnih veština, kao što su slušanje i čitanje sa razumevanjem, do produktivnih kao što su govor i pisanje. Očekivani rezultat kursa, odnosno nastave, jeste da svaki polaznik kursa savlada predviđeni standard datog nivoa (A1 ili A2) kako bi, ukoliko želi, mogao da nastavi pohađanje kursa slovačkog jezika na višim nivoima. Osnovni pristup u nastavi i usvajanju slovačkog jezika jeste komunikativni pristup u okviru kojeg se primenjuje uvod u jezički sistem i gramatiku slovačkog jezika putem predstavljanja i interpretacije, a nakon toga se ide u pravcu usvajanja leksike i sticanja komunikativnih veština.

Učenje slovačkog jezika kod polaznika čiji je maternji jezik srpski ima svoje specifičnosti, a oblici nastave i nastavne metode treba da budu usmerene ka maksimalnom trudu nastavnika da iskoriste tipološku bliskost i genetsku srodnost maternjeg i stranog jezika, da primene konfrontiranje i kontrastiranje datih jezika (fonologije, morfologije, sintakse i leksike), da nastavni materijal, zadatke i vežbe koncipiraju uzimajući u obzir jezičke greške nastale interferencijom bliskih slovenskih jezika i putem međujezičke homonimije. Međutim, postoje takođe jezičke pojave koje tokom usvajanja slovačkog jezika kao stranog kod studenata čiji je maternji jezik srpski utiču na brže razumevanje slovačkog jezičkog sistema i njegovo savladavanje: identične gramatičke kategorije i sličan sistem gramatičkih oblika, isti broj padeža i sličan princip deklinacije imenica, slični postupci komparacije prideva i priloga, sličan sistem glagolskih vremena, slični koreni pojedinih reči koje olakšavaju razumevanje nepoznatog teksta bez prethodno naučene reči ili upotrebe rečnika, itd. Kako bi usvajanje stranog jezika bilo efektivnije, didaktičke koncepcije, metode i strategija nastave treba da se određuju uzimajući u obzir i pomenute uticaje.

Ovaj rad predstavlja drugi deo rezultata dobijenih tokom istraživanja izučavanja slovačkog kao stranog jezika na Filozofskom fakultetu u Novom Sadu. Rezultati koji će biti predstavljeni i opisani u radu obuhvataju sledeće jezičke nivoe: morfolški, sintaksički i leksički. Prvi deo rezultata koji je

ského; Kamenárová, R., Gabríková, A., Ivoríková, H., Španová, E., Mošatová, M., Balšínková, D., Kleschtová, Z., Tichá, H. (2009). Krížom-krážom. Slovenčina A1 + A2 Cvičebnica. Bratislava: Univerzita Komenského 2009 (radna sveska); Kamenárová, R., Gabríková, A., Ivoríková, H., Španová, E., Mošat’ová, M., Balšínková, D., Kleschtová, Z., Tichá, H. (2011). Krížom-krážom. Slovenčina B1. Bratislava: Univerzita Komenského. 
obuhvatao ortografske i ortoepske greške polaznika slovačkog kao stranog jezika objavljen je u radu Ortografske i ortoepske greške učenika čiji je maternji jezik srpski pri usvajanju slovačkog kao bliskog slovenskog jezika (Tirova i Uhlarik, 2015).

Cilj rada jeste poboljšanje kvaliteta i strategija nastave i nastavnog materijala pri učenju slovačkog jezika kroz beleženje, objedinjavanje, klasifikovanje i analizu tipičnih morfoloških, sintaksičkih i leksičkih grešaka koje se javljaju kod polaznika slovačkog kao stranog jezika, a čiji je maternji jezik srpski.

Jezički materijal za analizu prikupljan je i beležen u toku tri školske godine na časovima slovačkog kao stranog jezika na Filozofskom fakultetu u Novom Sadu, kao i kroz testove koje su radili polaznici kursa. Svaki student je radio dva testa sa različitim vrstama zadataka (odabir pravilnog oblika reči ili konstrukcije, tvorba reči, rečenice ili mikroteksta, prevod mikroteksta, određivanje značenja pojedinih reči ili fraza, teorijska pitanja o gramatičkom sistemu slovačkog jezika). Istraživanje je trajalo tri godine i posmatrano je nekoliko grupa polaznika početnog kursa. Podaci o broju grupa, broju polaznika u grupama i urađenim testovima sažeti su u Tabeli 1.

\begin{tabular}{|l|c|c|l|}
\hline Školska godina & $\begin{array}{c}\text { Broj studenata } \\
\text { na kursu A1 }\end{array}$ & $\begin{array}{c}\text { Broj studenata } \\
\text { na kursu A2 }\end{array}$ & $\begin{array}{l}\text { Ukupan broj studenata po } \\
\text { školskoj godini na kursu A } \\
\text { (A1+A2) }\end{array}$ \\
\hline $2011 / 2012$. & 37 & 6 & 43 \\
\hline $2012 / 2013$. & 39 & 6 & 45 \\
\hline $2013 / 2014$. & 27 & 7 & 34 \\
\hline $\begin{array}{l}\text { Ukupan broj } \\
\text { studenata po nivoima } \\
\text { u toku tri školske } \\
\text { godine }\end{array}$ & 103 & 19 & $\begin{array}{l}\text { Ukupan broj studenata } \\
\text { u toku tri školske godine: } \\
\text { 122 }\end{array}$ \\
\hline $\begin{array}{l}\text { Ukupan broj } \\
\text { analiziranih testova }\end{array}$ & 206 & 38 & $\begin{array}{l}\text { Ukupan broj analiziranih } \\
\text { testova: } \\
\mathbf{2 4 4}\end{array}$ \\
\hline
\end{tabular}

Tabela 1. Podaci o broju grupa, broju polaznika u grupama i urađenim testovima 
Tokom istraživanja polazili smo pre svega od nekih teorijskih i praktičnih rezultata slovačke lingvistkinje J. Pekarovičove (1993, 2000, 2002, 2004), dobijenih na osnovu njenih dugogodišnjih istraživanja vezanih za izučavanje slovačkog kao stranog jezika.

\section{MORFOLOGIJA}

\subsection{Deklinacija imenica i prideva}

U slovačkom jeziku razlikujemo imenice muškog, ženskog i srednjeg roda. Kod imenica muškog roda je za promenu značajna i kategorija živo - neživo, tj. pripadnost kategoriji bića ili pripadnost kategoriji predmeta. Pod bićem se podrazumevaju lica i zanimanja. Nazivi životinja (muškog roda) spadaju u kategoriju neživo s tim da se u jednini menjaju po kategriji živo, a u množini po kategoriji neživo.

Većina imenica se menja po rodu, broju i padežu, osim izuzetaka koji imaju samo jedninu (singularia tantum) ili samo množinu (pluralia tantum). U slovačkim starijim gramatikama se govorilo o sedam padeža jer se uzimao u obzir i vokativ kao padež za oslovljavanje. Pošto vokativ ima poseban oblik samo u retkim slučajevima, a po pravilu je istovetan sa nominativom, današnje gramatike slovačkog jezika navode šest padeža u jednini i u množini. Detaljniju gramatiku slovačkog jezika pogledajte kod M. Tir i Z. Tirova (Tir i Tirova 2005: 11-29).

Uprkos ranijim tvrdnjama da je slovačka morfologija pravilna i relativno jednostavna (Baláž 1986: 38) savremena istraživanja su došla do zaključaka da bi dosadašnji sistem izučavanja deklinacija u slovačkom jeziku bilo potrebno inovirati (Pekarovičová 2000: 163). Ovaj sistem još nije do kraja razrađen, te se na Filozofskom fakultetu u Novom Sadu pri učenju slovačkog kao stranog koristi sistem po kom imamo sledeće paradigme: imenice muškog roda menjaju se po četiri tipa (uzora), imenice ženskog roda po pet tipova i imenice srednjeg roda po četiri tipa. Za imenice muškog roda to su paradigme 1. Muški rod - kategorija živo tip chlap (u N sg. bez nastavka ili sa nastavkom -o, u G. sg. -a) i tip hrdina (u N sg. nastavak - $a$, u G sg. -u); 2. Muški rod - kategorija neživo tip $d u b(\mathrm{u} \mathrm{N}$ sg. bez nastavka, u G. sg - $a$ ili -u; ove imenice se završavaju na tvrd ili neutralan suglasnik), tip stroj (u N sg. bez nastavka, u G sg. - $a$ ili - $u$; završavaju se na mek suglasnik). Kod imenica ženskog roda su tipovi žena (u N sg. nastavak $-a$ ispred kojeg se nalazi tvrdi ili neutralni suglasnik, u G sg. -y), ulica (u N sg. nastavak $-a$ ispred kojeg se nalazi meki suglasnik, u G sg. -e), dlaň (u N sg. bez nastavka, 
u G sg. -e; ove imenice se završavaju na meke i neke neutralne suglasnike), kost' (u N sg. bez nastavka, u G sg. -i; ove imenice se završavaju na meke i neke neutralne suglasnike) i gazdiná (u N sg. nastavak -á, u G sg. -ej; to su malobrojne imenice). Za srednji rod postoje tipovi mesto (u N sg. nastavak -o, u G sg. -a), srdce (u N sg. nastavak -e, u G sg. -a), vysvedčenie (u N sg. nastavak -ie, u G sg. -ia) i dievča (u N sg. nastavak - $a$, u G sg. proširen nastavak -ata; u množini svi padeži imaju po dva oblika).

Kod deklinacija najčešće dolazi do grešaka kod imenica koje imaju u nominativu jednine isti oblik u oba jezika, a u slovačkom kod određenih padeža dolazi do razmimoilaženja. Neki od primera za G sg. gde su studenti najčešće grešili su sledeći: uju (uja)ª slze (slzy), škvrne (škvrny), zime (zimy), stoličke (stoličky), banáne (banány); D sg. bratu (bratovi); I sg. hodinom (hodinou), s mamu (mamou), s mamom (mamou); G pl. fl'ak (flakov), krav (kráv), slzov (síz), škvrnov (škvín), zim (zim), vajičok (vajičok); N pl. slnke (slnká), žene (ženy), sestre (sestry), žabe (žaby), stôli (stoly), myše (myši), muche (muchy), flaši (fl'aše), stanici (stanice), splužiačke (spolužiačky), manželovia (manželia); I pl. hostima (host'mi).

U slovačkom jeziku, kao i u srpskom postoji kongruencija u rodu, broju i padežu. Vrlo često dolazi do grešaka usled činjenice da postoji razlika u rodu kod određene imenice u srpskom i slovačkom jeziku: čierny korenie (čierne), bielo víno (biele), žltý slnke (žlté slnká), zelený žabe (zelené žaby), s dobrom kamarátkom (s dobrou kamarátkou), malá káčatká (malé), zaplaveny mestá (zaplavené), vel'ki mestá (vel'ké mestá), stoly sú dreveni (drevené), vel'ka mesta (vel'ké mestá), červená trička (červené tričká), červeno tričko (červené), staršia bratia (starši bratia). Osnovne razlike kod prideva su sledeće: kod imenica srednjeg roda u slovačkom je nastavak -é umesto -o (lepo dete - pekné diet’a); u množini postoje nastavci za imenice muškog roda kategorije živo (pekní muži) i isti nastavci za imenice ženskog i srednjeg roda (pekné stoly, pekné ženy, pekné deti), dok se u srpskom jeziku nastavci razlikuju, te će biti lepi muškarci, lepi stolovi, lepe žene, lepa deca.

Kod prideva vrlo često dolazi do nepravilnosti kod pisanja dužina: staršía (staršia), krasný (krásny), bielý (biely).

\subsection{Brojevi u slovačkom jeziku u poređenju sa srpskim}

3 U zagradama su navedeni pravilni oblici datih reči. 
Brojevi u slovačkom i srpskom jeziku se ne razlikuju u velikoj meri. Razlike se javljaju zbog sopstvenog istorijskog razvoja svakog od pomenutih jezika. O brojevima u slovačkom i srpskohrvatskom jeziku pisao je M. Tir (Týr 1991).

Osnovni brojevi u slovačkom i srpskom jeziku su slični. Broj jedan kongruira sa nabrajanjem predmeta u rodu, broju i padežu. Ima posebne oblike za muški, ženski i srednji rod u jednini i u množini: jedan učenik - jeden žiak, jedno mesto - jedno miesto, jedni učenici - jedni žiaci. U slovačkom jeziku u množini muškog roda bezličnog oblika, ženskog roda i srednjeg roda javlja se tvrdo y: jedni hrastovi — jedny duby, jedne učenice — jedny žiačky, jedna mesta - jedny miesta.

Broj $d v a$ u slovačkom jeziku se u nominativu množine javlja u tri oblika: dvaja žiaci (m. r. bezličan oblik), dva duby (m. r. lični oblik), dve ženy (̌̌. r.), dve mestá (sr. r.). U srpskom jeziku postoje dva oblika u nominativu: dva grada, dva učenika, dva hrasta (m. r. i sr. r.) i dve učenice (ž. r.).

Broj tri u slovačkom jeziku ima u nominativu dva oblika: traja žiaci (m. r. lični oblik), tri duby, tri ženy, tri miesta (m. r. bezlični oblik, ž. r. i sr. r.). U srpskom jeziku postoji samo jedan oblik za sva tri roda: tri učenika, tri hrasta, tri žene, tri mesta.

Broj četiri se u slovačkom jeziku javlja u dva oblika: štyria žiaci (m. r. lični oblik) i štyri duby, ženy, mestá (sve ostale imenice). U srpskom jeziku postoji samo jedan oblik: četiri učenika, hrasta, žene, mesta.

Brojevi od pet do deset u slovačkom jeziku mogu kod ličnih imenica muškog roda imati dva oblika: sedem žiakov - siedmi žiaci. U srpskom jeziku imaju u nominativu samo jedan oblik: sedam đaka, deset devojčica, pet jabuka itd.

Brojevi od jedanaest do devetnaest u slovačkom jeziku završavaju na morfemu -nást': jedenást', dvanást', trinást', devätnást', dok u srpskom jeziku postoji morfema -naest: jedanaest, dvanaest, trinaest, devetnaest. Što se tiče desetica, brojevi u srpskom jeziku imaju samo morfemu -deset: dvadeset, trideset, devedeset. U slovačkom jeziku se javljaju dva morfemska nastavka -dsat' i -desiat: dvadsat', tridsat', štyridsat', pet'desiat, devät'desiat.

Broj sto u oba jezika zvuči i piše se isto s tim što u srpskom jeziku postoji mogućnost da se kaže i stotina. Ostali brojevi: hiljada - tisic, milion - milión, milijarda - miliarda.

Kod osnovnih brojeva su kod studenata evidentirane određene greške. Do njih dolazi uglavnom kada studenti ne prepoznaju pravilan rod imenice, ili zaborave na činjenicu da postoje imenice muškog roda kategorija živo, dok se za imenice ženskog roda podela na kategoriju živo - neživo ne primenjuje. 
Tako je došlo do sledećih tipskih grešaka odnosno do promene roda: dva bratia (dvaja), dva knihy (dve), dva múzeá i dvaja múzeá (dve), dva ujovia (dvaja), dvaja obrazy i dve obrazy (dva), jeden dieta (jedno), jeden klubovña (jedna), štyri učitelia (štyria), štyri žiaci (štyria), štyria knihy (štyri), štyria učitel'ky (štyri), traja hodiny (tri), tri synovia (traja), tri učitelia (traja). Drugi tip grešaka kod osnovnih brojeva je pogrešno zapisivanje broja: četyri hodiny (štyri), štarija žiaci (štyria), try galérie (tri).

Redni brojevi i u srpskom i u slovačkom jeziku se grade od osnovnih brojeva. U oba jezika do broja 4. menjaju se korenske morfeme (prvi - prvý, drugi - druhý, treći - tretí, četvrti- štvrtý). Kod rednih brojeva od 5. do 10. u slovačkom jeziku se samoglasnik u korenu menja u diftong: piaty, šiesty, siedmy, osmy, deviaty, desiaty. U srpskom jeziku se kod ovih brojeva na osnovu dodaje nastavak -i, i u sedmi, osmi dolazi do gubljenja samoglasnika a. Brojevi od 11 . do 20. i od 30. do 90. završavaju se na $-i$ i u srpskom i u slovačkom jeziku, s tim što se u slovačkom jeziku radi o tvrdom y: jedanaesti - jedenásty, dvadeseti dvadsiaty, trideseti - tridsiaty, devedeseti - devät'desiaty. Što se tiče brojeva kao što su: sto, hiljada, milion i milijarda u ova dva jezika imaju sledeće oblike: stoti — stý, hiljaditi - tisíci, milioniti - miliónty. Što se tiče trocifrenih i višecifrenih brojeva oblik rednog broja imaju samo desetice i jedinice, npr. broj 1725. se piše tisic sedemsto dvadsiaty piaty. U srpskom jeziku kod trocifrenih i višecifrenih brojeva oblik rednog broja ima samo poslednji broj u nizu 1986. hiljadu devetsto osamdeset (i) šesti. Upravo ovde studenti najviše greše. Tako je, npr. kod studenata bilo sledećih zapisa: dvadsat' piaty (dvadsiaty piaty), tridsat' siedmy (tridsiaty siedmy).

\subsection{Glagoli}

U slovačkom jeziku glagoli različitim oblicima izražavaju sledeća gramatička značenja: 1. gramatičko lice je prvo, drugo i treće: padám-padáme, padáš - padáte, padá - padajú; 2. gramatički broj je jednina (singular) i množina (plural): padám, padáś, padá - padáme, padáte, padajú; 3. glagolsko vreme je sadašnje (padám), prošlo (padal som) i buduće (budem padat); 4. glagolski način je indikativ (iskazni način), imperativ (zapovedni način) i potencijal (pogodbeni način); 5. glagolski rod je aktivni (chválim) i pasivni (som chválený). Pošto su ova gramatička značenja slična kao u srpskom jeziku, studentima je relativno lako da savladaju slovački glagolski sistem.

Sadašnje vreme se gradi od prezentske osnove nastavcima $-m,-\check{s}$ i nula u jednini i -me, -te i -ú ili -ia u množini (za slovački jezik) i nastavcima -m, -š i nula u jednini i -me, -te i - $u$ ili -e u množini (za srpski jezik). U slovačkom 
(nesiem, nesieš, nesie, nesieme, nesiete, nesú/robia), a u srpskom (nosim, nosiš, nosi, nosimo, nosite, nose/pišu).

$\mathrm{Na}$ osnovu ovoga se može zaključiti da problem predstavlja 1. lice množine, 3. lice jednine i 3. lice množine. Studentima treba skrenuti pažnju na to da se kod 2. lica množine nastavak -te čita meko. Kod čitanja studenti ovde često prave grešku.

Kod prezenta su se javile sledeće nepravilnosti, odnosno nepravilni nastavci i izostavljanje dužina: počúvaju (počúvajú), myslil (myslel), vidiel (videl), svietle (svietia), rozumeju (rozumejú), robía (robia), robiš (robišs), vyšetrove (vyšetruje), mate (máte), sediú (sedi), počuvaju (počúvajú), stoji (stoji), opakovame (opakujeme), čitam (čitam), boli (boli), ma (má), nejé (neje), pracuju (pracujú), stoje (stoja).

I u slovačkom i u srpskom jeziku futur je složen lični glagolski oblik i obeležava radnju koja će se vršiti posle vremena govorenja. ${ }^{4}$ Osnovna razlika je ta, da u srpskom postoji futur I koji označava radnju koja će se vršiti ili izvršiti u budućnosti, posle momenta govora (Primićemo poruku; Sutra ću sve nadoknaditi), a futur II se odnosi na nerealizovanu radnju za koju se pretpostavlja da će se desiti posle momenta govora, ali pre, posle ili za vreme neke druge radnje (Uzmi ono što budeš našao). U slovačkom jeziku, futur je glagolski oblik koji se takođe izražava na dva načina, ali u zavisnosti od glagolskog vida.

Kada su u pitanju glagoli nesvršenog vida, futur se gradi uz pomoć pomoćnog glagola byt' (biti) i infinitiva određenog glagola:

$\begin{array}{ll}\text { budem volat' } & \text { budeme volat' } \\ \text { budeš volat' } & \text { budete volat' } \\ \text { bude volat' } & \text { budú volat' }\end{array}$

Kod svršenih glagola oblikom sadašnjeg vremena se iskazuje buduća radnja (svršeni glagoli su npr. napisat', prečitat', odist'):

$\begin{array}{ll}\text { zavolám } & \text { zavoláme } \\ \text { zavoláš } & \text { zavoláte } \\ \text { zavolá } & \text { zavolajú }\end{array}$

Najčešće greške nastaju kada studenti ne prepoznaju da je glogol svršen, te buduće vreme grade kao za oblik nesvršenog glagola: bude sa zoznámit' (zoznámi sa), bude si nájst' (nájde si), bude si pozriet' (pozrie si), bude strávit' (strávi), budeme povedat' (povieme), povedámo (povieme).

Glagol ist' (ići) ima nepravilnu promenu

pôjdem

pôjdeme

4 Za srpski jezik pogledati Gramatiku srpskog jezika (Klajn 2005), a za slovački Slovenská gramatika (Pauliny - Ružička - Štolc 1968). 
$\begin{array}{ll}\text { pôjdeš } & \text { pôjdete } \\ \text { pôjde } & \text { pôjdu }\end{array}$

te on pravi najveće teškoće studentima. Kod studenata su se javljale sledeće nepravilnosti: budeš ist', pojdem, budem pôjdem, budem išla, budeš ist'.

Studenati su kod svršenih glagola buduće vreme gradili od futura pomoćnog glagola byt' (biti) i oblika prezenta svršenog glagola: budeš cvičí, bude obeduje, budú hrajú ili prezenta glagola byt' i infinitiva datog glagola: sú zjest', sme pisat'.

Najveći problem je predstavljao glagol zjest’ (pojesti) koji ima nepravilan oblik i trebao bi da glasi:

$\begin{array}{ll}\text { zjem } & \text { zjeme } \\ \text { zješ } & \text { zjete } \\ \text { zje } & \text { zjedia }\end{array}$

ali se pojavljivao u futuru u sledećim nepravilnim oblicima: deti sú zjel, deti zje, deti zjejú, deti zjú, budú zjest'.

Problem je, takođe, predstavljala i negacija u budućem vremenu. U slovačkom jeziku se gradi tako, da negacija ide uz pomoćni glagol, te bi trebalo da se kaže: nebudú vidiet' umesto pogrešnih oblika budú nevidiet', budú nerobit' kako su pisali studenti.

U srpskom jeziku postoji više glagolskih oblika kojima se obeležava prošlost nego u slovačkom. U srpskom postoje: perfekat, imperfekat, pluskvamperfekat i aorist, dok u slovačkom jeziku imamo samo perfekat i davno prošlo vreme.

U slovačkom jeziku postoje dva glagolska oblika za izražavanje prošlog vremena: prošlo vreme (minulý čas), koje odgovara srpskom perfektu i davnoprošlovreme (dávnominulý čas) koje odgovara pluskvamperfektu u srpskom jeziku. Na početnom nivou studenti koji uče slovački jezik uče samo prošlo vreme, koje se u slovačkom jeziku gradi od radnog glagolskog prideva na - $l$ i prezentskih oblika pomoćnog glagola byt:

$\begin{array}{ll}\text { volal/volala som } & \text { volali sme } \\ \text { volal/volala si } & \text { volali ste } \\ \text { volal/volala } & \text { volali }\end{array}$

U 3. licu jednine i množine, za razliku od srpskog jezika, nema pomoćnog glagola. U množini za sve rodove imamo -li: chlapi/ženy/deti volali za razliku od srpskog jezika gde imamo sledeće oblike muškarci su zvali, žene su zvale, deca su zvala. U ova dva slučaja studenti najčešće prave greške. Od 27 studenata, u jednom zadatku gde je bilo potrebno staviti oblik prošlog vremena za 3. lice jednine i množine, čak 8 studenata je stavljalo i pomoćni glagol. Primeri za ove greške su: sú zjedli, je cestovala, je letela, je myslela, je videl, sú čakali, 
je pracovala, je videl, čakali su, pojedol je, sú cestovali, su čekali, su mali, sú rozumel, su videli, vy povedali, je cestovala, je bola. Primeri za pogrešno navedene oblike radnog glagolskog priloga pod uticajem srpskog su sledeći: deti sú zjedla, je čekao, sú zjedle, smo male. Primeri za pogrešan oblik radnog glagolskog priloga: zjeli, zjelo, jedly, jesli, jeli, jela, zjedoli, vidieli, zabudnul, mogeli, neveli, myslil, chciel, nerozumiel. Postoje primeri gde pomoćni glagol za 1. lice jednine nije pravilno upotrebljen (u slovačkom je pravilan oblik sme): smo povedali, smo videli.

Još jedan tip grešaka se pojavljuje kod glagola. A to je slučaj, kada se u prvom i drugom licu izostavlja pomoćni glagol biti: my chodili, vy boli, my mali, vy niesli, vy videli.

Osnovna razlika između slovačkog i srpskog jezika je u građenju perfekta u 3. licu jednine i 3. licu množine gde nije izražen oblik pomoćnog glagola. Razlika je takođe i u odričnom obliku perfekta. U srpskom se odrični oblik gradi negiranim prezentom glagola jesam (nisam pisao, nisi pisao, nije pisao, itd.), a u slovačkom se gradi dodavanjem prefiksa $n e$ - ispred radnog glagolskog prideva. Odrični oblik u slovačkom jeziku bi bio nepisal som, nepisal si, nepisal.

Razlika u iskazivanju pitanja u prošlom vremenu u ova dva jezika je u tome što se u srpskom jeziku upotrebljava duži (naglašeni) oblik pomoćnog glagola jesam uz rečcu li (ili se pitanje postavlja pomoću konstrukcije da li), a u slovačkom red reči ostaje isti kao u afirmativnom obliku prošlog vremena, $\mathrm{s}$ tim što se pravi razlika u intonaciji. Na srpskom bismo rekli: Jeste li dobro videli? Da li si bio u pozorištu juče? dok bi na slovačkom to glasilo ovako: Videl si v kine moju sestru? Prečitali ste tú knihu? Kod ovakvih rečenica, studenti uglavnom nisu pravili greške, ali je kod čitanja primećena pogrešna intonacija.

\section{SINTAGMATIKA I SINTAKSA}

Znanje o gramatičkom sistemu slovačkog jezika dopunjuju informacije o sintagmatici i sintaksi slovačke rečenice. Na kursevima nivoa A polaznici se upoznaju sa elementarnim delom sintaksičkog sistema slovačkog jezika. U tom kontekstu je pre svega važna klasifikacija vrste reči na autosemantičke i sinsemantičke i sagledavanje njihovih sintaksičkih funkcija. Osnovnom znanju o sintaksi pripada građenje sintagmi (koordinacija, determinacija i predikacija) i razlikovanje odnosa između reči u sintagmi (kongruencija, rekcija i adjunkcija) koje polaznici usvajaju od početka kursa kroz pismene i oralne zadatke. U okviru kursa nivoa A polaznici stiču elementarno znanje o slovačkoj rečenici. Osnovni rečenički tip slovačkog jezika jeste personalna rečenica (tzv. dvočlana 
rečenica) čiju bazu čini predikativna sintagma (subjekat i predikat). Međutim, u srpskom jeziku, slično kao u slovačkom, subjekat ne mora biti uvek eksplicitno iskazan, već je poznat na osnovu prethodnog ili sledećeg konteksta, ali su njegove gramatičke kategorije prepoznatljive na osnovu ličnog oblika glagola u predikatu (Uhláriková 2009: 92). Često se, međutim, javlja preterana upotreba ličnih zamenica u funkciji subjekta, koja polaznicima kursa olakšava tvorbu rečenice, npr.: Ja se volam Darko. Ja mám brata. Ja žijem v bytem s rodičmi. Ja študujem v Novom Sadu. Mám dvadeset rokov. Mám auto a psa, a volá se Čeda. U navedenim primerima ličnu zamenicu $j a$ treba izostaviti, a rečenicu početi glagolom: Ja sa volám Darko. Mám brata. Žijem v byte s rodičmi. Študujem v Novom Sade. Mám dvadsat rokov. Mám auto a psa a volá sa Čeda.

Kod studenata sa srpskog govornog područja u okviru sintakse slovačkog jezika probleme često pravi upotreba leksičkih morfema sa i si kod povratnih glagola. Iako se red reči u slovačkoj rečenici uglavnom definiše kao proizvoljan, ipak postoje neka ograničenja. Neka od tih ograničenja tiču se upravo morfema $s a$ ili si kod povratnih glagola kao jedna od tipičnih grešaka tokom usvajanja slovačke sintakse. Leksička morfema sa ili si treba po pravilu da stoji ispred glagola kada je povratni glagol upotrebljen u sredini ili na kraju rečenice. Ukoliko rečenica počinje povratnim glagolom morfema sa ili si treba da stoji iza glagola. Rečenica ne može početi morfemom sa/si. Npr:

Moja sestralOna sa volá Vesna. Volám sa Vesna.

Brat/On sa umýva. Umýva sa.

My si želáme pekné počasie. Želáme si pekné počasie.

Možemo izdvojiti nekoliko faktora zbog kojih dolazi do pogrešne upotrebe leksičkih morfema $s a$ i $s i$ :

a) pogrešna upotreba morfeme iza glagola zbog primene glagola u primarno naučenom obliku u infinitivu (volat'sa, rozprávat' sa, mysliet' si), npr: Ona vola sa Anastasija. Moja mama volá sa Valerija (umesto pravilnog: Ona sa volá Anastasija. Moja mama sa volá Valerija.),

b) pogrešna upotreba morfeme ispred glagola zbog pokušaja da se izbegne često ponavljanje lične zamenice, npr: $\boldsymbol{S a}$ volám Dražen. Mám brata. Sa volá Miloš (umesto pravilnog: Volám sa Dražen. Mám brata. Volá sa Miloš.),

c) pogrešan red reči u rečenici zbog automatskog preslikavanja srpskog oblika sviđa mi se kao páči mi sa umesto pravilnog páči sa mi ili najviše mi se sviđa kao najviac mi sa páči umesto pravilnog najviac sa mi páči, npr: Páči mi sa jarna priroda; Najviac mi sa páči zima; Najviac mi sa páči rychla a dynamicka hudba (umesto pravilnog: Páči sa mi jarná príroda; Najviac sa mi páči zima; Najviac sa mi páči rýchla a dynamická hudba.), 
d) pogrešno izostavljanje morfeme sa ili si kod glagola koji za razliku od slovačkog jezika u srpskom jeziku nisu povratni glagoli, npr: Pod vianočny stromček želám zaujímavu knihu (umesto pravilnog: Pod vianočný stromček si želám zaujímavu knihu); Želám nový počitač pod vianočný stromček (umesto pravilnog: Želám si nový počitač pod vianočný stromček); Učim slovenský jazyk (umesto pravilnog: Učim sa slovenský jazyk); V meste bývajú mladi ludia z ktorymi môžem vždy porozprávat' (umesto pravilnog: V meste bývajú mladí l'udia, s ktorými sa môžem vždy porozprávat'), itd.

Za iskazivanje odnosa i tvorbu sintagmi i rečenica u slovačkom jeziku je važna pre svega kategorija padeža koji funkcioniše kao primarni pokazatelj odnosa među rečima i konstrukcijama. Osim osnovne funkcije subjekta u rečenici, imenice se nalaze i u funkciji imenskog dela predikata, objekta ili adverbijala. Za realizaciju željenog značenja slovački jezik zahteva objekat ili adverbijal iskazan imenicom u određenom padežu sa ili bez odgovarajućeg predloga, npr.: Dobre hovorím po slovensky (adverbijal za način, po + L) ili Idem $\boldsymbol{k}$ moru (adverbijal za mesto, $\mathrm{k}+\mathrm{D}$ ). Kod ovih jezičkih pojava se često javlja puko preslikavanje srpskog oblika padeža sa ili bez predloga koji se automatski importuje u slovačku rečenicu, npr: Róbert dobre hovori slovensky/slovački/na slovenski/po slovački/po slovančina; Vtedy ja idem na more (umesto pravilnog: Róbert dobre hovorí po slovensky; Vtedy ja idem $k$ moru). Međutim, upotreba ili prevođenje predloga i padeža po principima srpskoga jezika mogu da dovedu do pomeranja i pogrešne interpretacije semantike iskaza pošto predlog i padež imaju i distinktivnu funkciju, npr: rečenica tipa Cestujem do Belehradu se u početnoj fazi učenja jezika prevodi pogrešno Putujem do Beograda. Treba obratiti pažnju na sledeće konstrukcije i njihova značenja:

slov. cestujem do Belehradu $\rightarrow$ srb. putujem u Beograd

srb. putujem do Beograda $\rightarrow$ slov. cestujem po Belehrad

U slovačkom jeziku je red reči sličan kao u mnogim evropskim jezicima: subjekat - predikat - objekat. Ukoliko neki od rečeničkih članova ima determinant $\mathrm{u}$ vidu atributa, onda atribut stoji ispred imenice ili neke druge imenske reči koju bliže determiniše. U ovom kontekstu se javljaju greške morfološkog karaktera, odnosno u okviru kongruencije, koje su u datoj fazi učenja jezika (nivo A) prihvatljive jer polaznici još nisu savladali celokupan sistem deklinacija. 


\section{LEKSIČKI FOND SLOVAČKOG JEZIKA - LEKSIČKI MINIMUM}

Leksički minimum predviđen za nivo A slovačkog jezika predstavljaju: a) najfrekventnije lekseme koje služe za imenovanje osnovnih realija, supstanci, statičkih i dinamičkih procesa i stanja (imenice, pridevi, glagoli), b) konstrukcijsko-gramatičke reči, deiktički identifikatori, orijentatori, lokalizatori (zamenice, predlozi, veznici, pomoćni i modalni glagoli, prilozi, rečce), c) najproduktivniji derivacioni postupci tvorbe reči i značenja, forme obogaćivanja leksičkog fonda i specifičnosti tvorbe imeničkih, pridevskih i glagolskih naziva. Početni kurs slovačkog jezika obuhvata elementarni leksički fond na nivou A1 (od 800 do 1000 reči) i na nivou A2 (svakodnevna komunikacija od 1400 do 2000 reči). Svaki polaznik kursa svoj lični fond reči proširuje učenjem novih reči u okviru obrađenih tema na časovima konverzacije (predstavljanje sebe i drugih, porodica, ljudsko telo, rodno mesto, oblačenje, odlazak u kupovinu, ishrana, odlazak u restoran, odlazak kod lekara i u apoteku, slobodno vreme, odlazak na muzički koncert, kampovanje, letovanje i slično). U okviru jedne teme polaznici nauče oko 100 novih reči.

Stručna lingvistička terminologija je na ovom kursu svedena na minimum i koristi se u onoj meri koja je neophodna za razumevanje i učenje sistema slovačkog jezika $s$ obzirom na to da ciljne grupe ovih kurseva čine pretežno nelingvisti.

Leksički minimum obuhvata i usvajanje frazeološkog i paremiološkog minimuma. U nekim ranijim kontrastivnim analizama slovačke i srpske frazeologije došli smo do saznanja da je očigledna prisutnost velikog broja identičnih $^{5}$ frazema u slovačkom i srpskom jeziku. (Uhláriková 2012: 310-311). Stoga usvajanje osnovne slovačke frazeologije kreće od identičnih frazema, npr.: dobrá rada nad zlato $\rightarrow$ dobar savet zlata vredi, žit' na vysokej nohe $\rightarrow$ živeti na visokoj nozi. Kasnije se učenje novih frazema realizuje kroz međujezičko poređenje frazema, tako što studenti dobiju zadatke u kojima treba da pronađu semantički ekvivalent frazema u srpskom jeziku uz pomoć frazeoloških rečnika, kao i da nevedu opisno objašnjenje pojedinih frazema. Usvajanje frazema kod polaznika kursa počinje na nivou A2 (druga godina učenja jezika). Usvajanje i poznavanje frazeološkog bogatstva jezika čini deo komunikativne kompetencije polaznika čiji iskaz stiče nijansu etnokulturnog kolorita, a ujedno utiče na podizanje kulture jezičkog iskaza pojedinca.

5 Pod identičnim frazemima podrazumevamo frazeme koji su identični na nivou motivacije (u ekvivalentnom srpskom i slovačkom frazemu je ista zastupljenost leksičkih komponenata) kao i na strukturno-semantičkom nivou. 
Poseban problem predstavljaju interlingvalni homonimi usled kojih nastaju jezičke i komunikativne greške. Radi se o odnosu između leksema i semema kod kojih se javlja identična forma, ali se značenje razlikuje (vidi Tabelu br. 2). Međujezički homonimi su čest uzrok za nepravilno razumevanje sadržaja iskaza koje vodi ka neadekvatnoj interpretaciji ili barijeri u komunikaciji.

\begin{tabular}{|l|l|}
\hline slov. $\rightarrow$ srb. & srb. $\rightarrow$ slov. \\
\hline slovo $\rightarrow$ reč & slovo $\rightarrow$ písmeno \\
\hline reč $\rightarrow$ govor, jezik & reč $\rightarrow$ slovo \\
\hline mesto $\rightarrow$ grad & mesto $\rightarrow$ miesto \\
\hline slovenský $\rightarrow$ slovački & slovenski $\rightarrow$ slovanský \\
\hline líce $\rightarrow$ obraz & lice $\rightarrow$ tvár \\
\hline obraz $\rightarrow$ slika & obraz $\rightarrow$ líce \\
\hline hodina $\rightarrow$ sat (sat vremena) & godina $\rightarrow$ rok \\
\hline vôňa $\rightarrow$ miris (lep miris) & vonj $\rightarrow$ zápach \\
\hline lepšínajlepší $\rightarrow$ bolji/najbolji & lepši/najlepši $\rightarrow$ krajší/najkrajšíi \\
\hline rodina $\rightarrow$ porodica & rodbina $\rightarrow$ príbuzní \\
\hline trh $\rightarrow$ pijaca & trg $\rightarrow$ námestie \\
\hline druh $\rightarrow$ vrsta & drug $\rightarrow$ kamarát \\
\hline prezývka $\rightarrow$ nadimak & prezime $\rightarrow$ priezvisko \\
\hline
\end{tabular}

Tabela br. 2.

U okviru naše analize izdvojili bismo još neka pogrešna rešenja kojima pribegavaju polaznici početnog kursa:

a) upotreba srpske reči umesto slovačke u rečenici, npr: Nový Sad je pekné mesto. Kroz (cez) mesto preteká rieka Dunaj; Má charakteristické zgrade (budovy); Tam mam puno knihy (vel'a kníh),

b) prilagođavanje srpske reči slovačkom jezičkom sistemu, npr: raspravl'at' (raspravljati $\rightarrow$ diskutovat', prerokúvat'),

c) upotreba dijalekatskog oblika reči kod studenata koji imaju kontakt sa Slovacima u Vojvodini, npr: Želám knihu alebo sto evrov preto, že chcem kupit' nový počitač (pravilno: eur); neni umesto pravilnog nie je (nije),

d) upotreba reči iz drugih slovenskih jezika, pre svega ruskog, npr: Nový god (Nový rok); tože (tiež, taktiež), poljskog, npr: pomidory (paradajky), hrvatskog, npr: tvornica (továreň). 


\section{ZAKLJUČAK}

Analizom zabeleženih podataka izdvojili smo i analizirali najfrekventnije morfološke, sintaksičke i leksičke greške studenata u cilju poboljšanja kvaliteta nastave slovačkog kao stranog jezika na Filozofskom fakultetu u Novom Sadu. Dobijeni rezultati mogu u velikoj meri pomoći pri učenju slovačkog kao stranog jezika skretanjem pažnje nastavnika (tokom pripreme nastavnog materijala, zadataka i vežbi), ali i studenata (tokom učenja i usvajanja novog stranog jezika) na očekivane i tipične greške. Kako bi rezultati nastave na početnom nivou učenja slovačkog jezika bili efektniji predlažemo:

a. skretati pažnju studentima na razlikovanje kategorije živo - neživo kod imenica muškog roda,

b. kroz usmene i pismene zadatke vežbati i ponavljati deklinacije i konjugacije sa permanentnim osvrtanjem na oblike koji se u slovačkom i srpskom jeziku razlikuju,

c. kroz pismene i usmene zadatke, kao i prevod mikroteksta vežbati sastavljanje rečenica sa obaveznom analizom grešaka studenata i poređenjem sintagmatskih $i$ rečeničkih konstrukcija u slovačkom i srpskom jeziku,

d. skretati pažnju studenata na upotrebu predloga sa određenim padežima i njihovo značenje,

e. proširivanje fonda reči uz istovremenu identifikaciju reči koje imaju zajednički koren u oba jezika, te su za studente često razumljive i bez prethodno naučene reči, kao i skretanje pažnje na međujezičke homonime.

Namerna i svesna konfrontacija dvaju jezika može da poveća stepen razumevanja semantičkih razlika, a smanji stepen negativnog transfera. $\mathrm{Na}$ osnovu svih stečenih saznanja i ovog istraživanja dolazimo do zaključka da bi sledeći korak u pravcu poboljšanja nastave slovačkog kao stranog jezika moglo biti koncipiranje udžbenika prilagođenih studentima sa srpskog govornog područja. Predlažemo sledeće postupke: određivanje optimalnog obima teorijskog znanja o jeziku, koncipiranje komunikativno usmerenih udžbenika, primena komunikativnog umesto kognitivnog pristupa, prevazilaženje tradicionalnih i primena modernih metoda, međujezičko poređenje maternjeg i stranog jezika, primena direktnih audio-oralnih metoda pri usvajanju stranog jezika kroz zadatke zasnovane na tvorbi i transformacijama reči, sintagmi, rečenica, teksta, mikroteksta i njihovom učestalom ponavljanju i vežbanju.

\section{LITERATURA}


Baláž, P. (1986). "Slovenčina ako cudzí jazyk", in Studia Academica Slovaca 15, ed. J. Mistrík (Bratislava: Alfa): 29-45.

Klajn, I. (2005). Gramatika srpskog jezika. Beograd: Zavod za udžbenike i nastavna sredstva.

Marić, A (2010). "Uticaj međujezičkih razlika na učenje bliskih jezika", in Susret kultura,ur. Lj. Subotić, I. Živančević-Sekeruš (Novi Sad: Filozofski fakultet): 909-917.

Pauliny, E. - Ružička, J. - Štolc, J. (1968). Slovenská gramatika. Bratislava: Slovenské pedagogické nakladatel'stvo.

Pekarovičová, J. (1993). "Slovenčina ako cudzí jazyk a odborná komunikácia“, in Studia Academica Slovaca 22, ed. J. Mlacek (Bratislava: STIMUL): $175-180$.

Pekarovičová, J. (2000). "Slovenčina ako cudzí jazyk v lingvodidaktickom kontexte“, in Studia Academica Slovaca 29, ed. J. Mlacek (Bratislava: STIMUL): $158-172$.

Pekarovičová, J. (2002). "Lingvodidaktická koncepcia slovenčiny ako cudzieho jazyka“, in Slovenčina ako cudzí jazyk, ed. J. Pekarovičová (Bratislava: STIMUL ): 11-26.

Pekarovičová, J. (2004). Slovenčina ako cudzi jazyk - predmet aplikovanej lingvistiky. Bratislava: STIMUL.

Tir, M. - Tirova, Z. (2005). Sa slovačkim u svet. Beograd: Agencija „Matić““.

Týr, M. (2004). Slovenčina v praxi. Novi Sad: Futura publikacije.

Týr, M. (1991). Čislovky v spisovnej slovenčine a v spisovnej srbochorvátčine. Nový Sad, Bratislava: Obzor - Tvorba, Vyfavatel'stvo ALFA.

Uhláriková, J. (2009). "Metaforická funkcia zámen", in Slovakistický zborník 4, ed. M. Týr (Nový Sad: Slovakistická vojvodinská spoločnost'): 90-104.

Uhláriková, J. (2012). "Slovenské a srbské frazémy s lexikálnym komponentom oko", in Diskursi manjinskih jezika, književnosti i kultura u jugoistočnoj i srednjoj Evropi, ur. M. Dudok (Novi Sad: Filozofski fakultet): 307-318. 
Jasna Uhlarik

jasna.uhlarik@gmail.com

Zuzana Tirova

zuzana.tyrova@gmail.com

University of Novi Sad

Faculty of Philosophy

Department of Slovak Studies

\section{MORPHOLOGICAL, SYNTACTICAL, AND LEXICAL ERRORS OF STUDENTS WHOSE MOTHER TONGUE IS SERBIAN WHILE LEARNING SLOVAK AS SIMILAR SLOVENIAN LANGUAGE}

\section{Summary}

During a three-year-long research and analysis of both classes of Slovak as a foreign language and students' work on such classes as well as their results on the tests, we have obtained the following: documentation, collection, classification, and analysis of the mistakes that appear in the process of learning Slovak as a foreign language with those students whose mother tongue is Serbian. By analyzing documented data, we have managed to separate and conduct additional analysis of the most frequent morphological, syntactical, and lexical errors that students make in order to improve the quality of lectures of Slovak as a foreign language on the Faculty of Philosophy in Novi Sad. Considering the fact that Slovak and Serbian language are genetically close languages it is not surprising that students show high level of understanding but also a significant interference of these two languages. The emphasis is put on: a) absence or differences related to certain linguistic characteristics: parallels, concurrence, and similarities as opposed to differences and contrasts in Slovak and Serbian language, b) expected and common errors that students make while learning, documented on beginners course classes of A1 and A2 level over the course of three academic years. Results of this research will be used in classes and for selection of adequate didactical concept and methodological approach to lectures. In process of improving class quality the following should be applied: determining optimal scope of theoretical knowledge of language, preparing communication oriented textbooks, taking up communicative rather than cognitive approach, overcoming traditional methods while adopting modern ones, inter-linguistic comparison of foreign language and mother tongue, applying direct audio-oral methods of adapting a foreign language through different tasks. Intentional confrontation of two languages can enhance the level of understanding of semantic differences while reducing the level of negative transfer at the same time. The most important step in improving the quality of classes of Slovak as a foreign language would be preparing textbooks adjusted to students from Serbian speaking area.

Key words: Slovak as a foreign language, Serbian as a mother tongue, inter-linguistic interference, morphology, syntax, lexicon, analysis of common errors, applying results

Primljeno: 31. 3. 2016.

Prihvaćeno: 16. 5. 2016. 